\title{
Human Contribution to the Variation of Runoff under Climatic Background over the Laohahe Basin, Northeast China
}

\author{
Luyan Gong ${ }^{1,2}$, Liliang Ren $1,2, * \mathbb{D}$, Shanshui Yuan ${ }^{3}$ and Shanhu Jiang ${ }^{1,2}$ \\ 1 State Key Laboratory of Hydrology-Water Resources and Hydraulic Engineering, 1 Xikang Road, \\ Nanjing 210098, China; gongluyan20@163.com (L.G.); hik0216@163.com (S.J.) \\ 2 College of Hydrology and Water Resources, Hohai University, Nanjing 210098, China \\ 3 Yangtze Institute for Conservation and Development, Hohai University, Nanjing 210098, China; \\ yuanshanshui@hhu.edu.cn \\ * Correspondence: RLL@hhu.edu.cn
}

check for updates

Citation: Gong, L.; Ren, L.; Yuan, S.; Jiang, S. Human Contribution to the Variation of Runoff under Climatic Background over the Laohahe Basin, Northeast China. Water 2021, 13, 2642. https://doi.org/10.3390/w13192642

Academic Editors: Achim A. Beylich and Elias Dimitriou

Received: 14 August 2021

Accepted: 22 September 2021

Published: 25 September 2021

Publisher's Note: MDPI stays neutral with regard to jurisdictional claims in published maps and institutional affiliations.

Copyright: (c) 2021 by the authors. Licensee MDPI, Basel, Switzerland. This article is an open access article distributed under the terms and conditions of the Creative Commons Attribution (CC BY) license (https:// creativecommons.org/licenses/by/ $4.0 /)$.

\begin{abstract}
The Laohahe basin is one of the typical semi-arid regions in Northeast China. Quantitatively estimating the contributions of human intervention and climatic variability on runoff changes in this region will help enhance the understanding of local hydrological mechanisms and provide an effective reference for water resources planning and management in other semi-arid regions of the world. The non-parametric Mann-Kendall test was used to analyze the temporal trends of annual precipitation, potential evapotranspiration (PET), and runoff in the whole Laohahe basin and its three sub-basins from 1964 to 2015. The annual runoff showed a decreasing trend in each sub-basin. The change-points of annual runoff detected by Pettitt's test and residual analysis based on double mass curves (RA-DMC) are 1979 and 1998, and the baseline period and change period of each basin are 1964-1979 and 1980-2015. The RA-DMC method and the VIC model were used to quantitatively evaluate the contributions of human intervention and climatic variability to runoff change, which vary in time and space over the past 52 years. The contributions of human intervention to runoff reduction during 1980-2015 was more than $80 \%$. On a multi-decadal temporal scale, human intervention had a stronger impact on runoff during 1980-1989, 2000-2009, and 2010-2015. The influence of human intervention on runoff reduction is gradually increasing in the 21st century. Besides, human intervention has a greater impact in dry years than in wet years. The increase of cropland area leads to a significant increase in irrigation area, which further leads to an increase in the demand for agricultural water, which is also the main reason for the sharp reduction of runoff in the Laohahe basin.
\end{abstract}

Keywords: runoff; human intervention; climatic variability; precipitation; hydrologic model; Laohahe basin

\section{Introduction}

Climatic variability and human intervention are two major factors affecting the regional/watershed hydrological cycle, which are hot topics in hydrology research. [1-3]. The impacts of climatic variability and human intervention on hydrological processes are two physical processes with different properties and spatial and temporal scales, coinciding and interacting with each other [4-7]. Especially in arid and semi-arid regions, the effects of climatic variability and human intervention are more sensitive to runoff, leading to serious water crises and environmental degradation. [8-14]. Therefore, quantitatively assessing the relative contributions of climatic variability and human intervention to runoff reduction is important, which is necessary for further understanding the basin's hydrological mechanism, the prevention and control of droughts and floods, and local water resources and basin planning.

Many hydrologists have tried to analyze the effects of climatic variability and human intervention on runoff processes in recent years. Most researchers use hydrological models 
to study the response of runoff processes to integrated climatic variability in different basin scenarios [15-17]. The Variable Infiltration Capacity (VIC) hydrological model was used by Chang et al. [18] to investigate the hydrological effect of climatic variability and human activity in Weihe River. Zeng et al. [19] used the SIMHYD and SWAT models to assess the contributions of climatic variability and human intervention in the Luanhe basin. Ma et al. [20] used GBHM distributed hydrological model to evaluate the reduction of inflow in Miyun Reservoir, where climate factors and human intervention reduced the inflow by $55 \%$ and $45 \%$, respectively. In the Fenhe river, the effect on runoff caused by human intervention and climatic variability has been investigated by Wang et al. [21] by using the SIMHYD model. Despite all the merits of the hydrological models, the accuracy of the model result is influenced by model structure, parameterization, and scale issues. Based on the factors outlined above, the streamflow change of the Laohahe basin caused by climatic variability and human intervention has been assessed via a method based on residual analysis according to double mass curves (RA-DMC) in this study. Kong et al. [22] firstly proposed the RA-DMC in 2016. Therefore, the excellent correlation between accumulated precipitation and runoff over the years provides favorable conditions for further quantitative analysis of the runoff changes caused by climatic variability and human intervention. Moreover, we have verified the dependability of the RA-DMC method by calculating the effects of human intervention and climatic variability in the VIC model.

The Laohahe basin, located at the headstream of Xiliao River in Northeast China, is one of the typical semi-arid regions in China and one of the most important agricultural production regions in North China for nearly half a century. The Laohahe River provides important water resources to parts of Liaoning, Hebei, and Inner Mongolia provinces. With the rapid development of the social economy, the impact of climatic variability and human intervention in the Laohahe basin has reduced the quality and quantity of available water resources in the basin, leading to environmental degradation, major rivers drying up, and other water resources crises. [8,23,24]. In recent decades, the Laohahe basin has been facing a serious water shortage problem, which has seriously hindered local agriculture and the economy [25]. Therefore, to realize the sustainable development of water resources in the Laohahe basin, it is of great significance to quantitatively evaluate the effect of climatic variability and human intervention on runoff. It has been reported that the streamflow of the Laohahe basin has distinctly decreased in recent years $[8,26]$. Yong et al. [7] revealed that the runoff decreasing was due to human intervention, such as new reservoirs and dams, and the rapid local economic development. Liu et al. [27] believed that the land use/land cover change increased evapotranspiration, which leads to a decrease in the runoff. Wang and $\mathrm{Li}$ [28] indicated that overexploitation and utilization of water resources caused a decrease in the runoff. Jiang et al. [8] evaluated the different quantitative impacts of climatic variability and human intervention on runoff change, but they did not discuss the investigation results. Therefore, it is necessary to study the quantitative impacts of climatic variability and human intervention on the spatial and temporal distribution of runoff in the Laohahe basin. In this study, there are three objectives: (1) Evaluate the long-term runoff changes in the Laohahe basin and three sub-basins; (2) Determine the mutation points of annual runoff in these basins; (3) Use the RA-DMC method and the VIC model to quantitatively evaluate the contribution rates of climatic variability and human intervention to runoff change in the Laohahe basin.

\section{Study Area and Data}

\subsection{Study Area}

The Laohahe basin $\left(41^{\circ} \mathrm{N} \sim 42.75^{\circ} \mathrm{N}, 117.25^{\circ} \mathrm{E} \sim 120^{\circ} \mathrm{E}\right)$ locates at the junction of Hebei Province, Liaoning Province, and Inner Mongolia Autonomous Region. The Laohahe River originates from the Guangtou Mountain, and flows northeastward into Chifeng City, then merges with the Xilamulun River flowing from west to east to become the Xiliaohe River. The Laohahe River is about $426 \mathrm{~km}$ long and has a total drainage area of $18112 \mathrm{~km}^{2}$. The terrain of the basin is low in the northeast and high in the southwest, and the meters 
above sea level (masl) rise from $427 \mathrm{~m}$ to $2057 \mathrm{~m}$. The basin is a typical semi-humid and semi-arid area. The annual precipitation in the basin is about $416.43 \mathrm{~mm}$ (of which about $80 \%$ is concentrated in May to September). The mean annual temperature in the past 50 years is $7.58^{\circ} \mathrm{C}$. The potential evapotranspiration (PET) and runoff are $1014.11 \mathrm{~mm}$ and $25.25 \mathrm{~mm}$, respectively.

In this study, we selected four basins in the Laohahe basin (Figure 1 and Table 1), including one headwater basin (Dianzi basin), two midstream basins (Chifeng basin and Taipingzhuang basin), and the whole Laohahe basin. The annual precipitation in these basins ranges from $400 \mathrm{~mm}$ to $550 \mathrm{~mm}$, and the annual runoff ranges from $20 \mathrm{~mm}$ to $70 \mathrm{~mm}$.

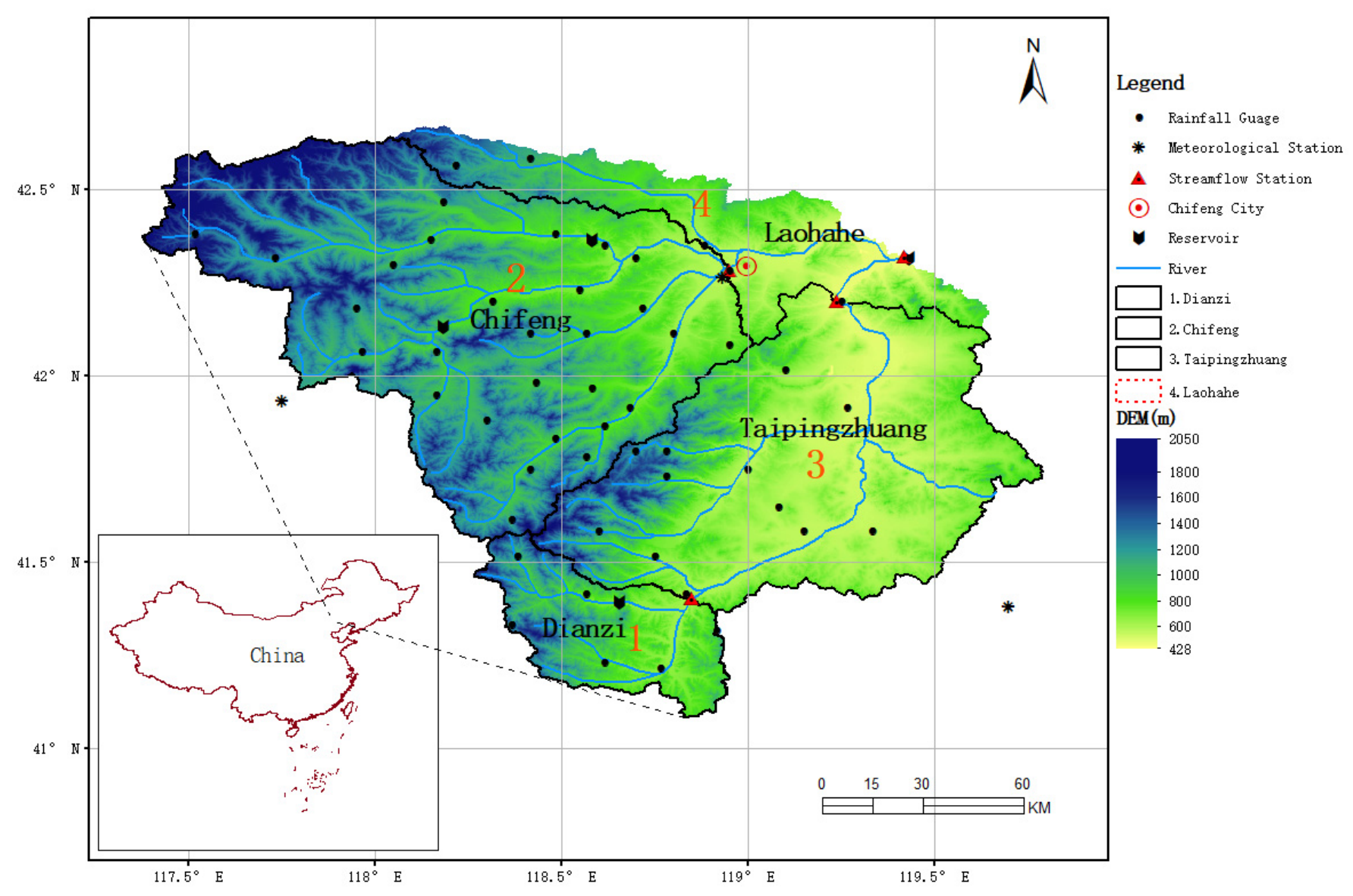

Figure 1. Location of the Laohahe basin and spatial distribution of measurement stations.

Table 1. Hydrological stations and hydrological characteristics of the four basins in the Laohahe basin.

\begin{tabular}{cccccccc}
\hline Basin & Streamflow Station & Lat (N) & Lon (E) & Area $\left.\mathbf{( k m}^{\mathbf{2}}\right)$ & masl $\mathbf{( m )}$ & Annual Runoff (mm) & Annual Precipitation (mm) \\
\hline 1. Dianzi & Dianzi & $41^{\circ} 25^{\prime}$ & $118^{\circ} 50^{\prime}$ & 1643 & 958.47 & 63.11 & 526.34 \\
2. Chifeng & Chifeng & $42^{\circ} 7^{\prime}$ & $118^{\circ} 57^{\prime}$ & 8678 & 1123.52 & 21.42 & 402.79 \\
3. Taipingzhuang & Taipingzhuang & $42^{\circ} 1^{\prime}$ & $119^{\circ} 15^{\prime}$ & 7720 & 777.62 & 27.04 & 441.13 \\
4. Laohahe & Xinglongpo & $42^{\circ} 19^{\prime}$ & $119^{\circ} 26^{\prime}$ & 18,112 & 938.70 & 25.25 & 416.43 \\
\hline
\end{tabular}

\subsection{Data}

In this study, the data include: (1) Terrain DEM data is extracted from ASTER Global Digital Elevation Model with a resolution of $30 \mathrm{~m}$ jointly issued by National Aeronautics and Space Administration (NASA) and the Japanese Ministry of Economy, Trade and Industry (METI); (2) Meteorological data at 4 reference stations from 1964 to 2015 are provided by the National Meteorological Administration, including daily maximum, minimum and mean temperature, $10 \mathrm{~m}$ average wind speed and sunshine duration; (3) Inner Mongolia Hydrological Bureau provided daily precipitation data at 52 rainfall stations, 
daily runoff data at four hydrological stations, and daily evaporation data at nine evaporation stations from 1964 to 2015; (4) Economic and social statistics are from the Chifeng City Statistics Bureau; (5) Large reservoir information is provided by local administration; (6) Soil data comes from the global soil data released by the World Food and Agriculture Organization (FAO); (7) Land use/cover data over four periods are obtained from remote sensing interpretations (1970s, Landsat3 MSS image interpretation in 1975/1976; 1980s, Landsat5 TM image interpretation in 1989; 1990s, Landsat7 ETM+ image interpretation in 1999; 2000s, Landsat5 TM image interpretation in 2007), which have been evaluated by the field surveys [29]; (8) Soil erosion data is from National Earth System Science Data Center, National Science \& Technology Infrastructure of China (http:/ / www.geodata.cn, accessed on 18 September 2021) in 1995.

\section{Methods}

\subsection{Trend and Change-Point Analysis Methods}

Mann-Kendall test: a rank-based Mann- Kendall (MK) trend test is used to quantify the trend and significance level for annual precipitation, PET, and runoff series [30,31]. The MK test does not assume any distributional form for the data and is as powerful as its parametric competitors. Meanwhile, we use Sen's slope method $[32,33]$ to estimate the magnitudes of the trends (slopes) based on Kendall's tau.

Pettitt's test: Pettitt's test [34] is a non-parametric approach to determine the occurrence of a change point. This method is widely used to detect change points of hydrological and meteorological variables, and the calculation steps are simple.

\subsection{Double Mass Curves Derived Residual Analysis}

Runoff is not simultaneous to precipitation. Specifically, precipitation is prior to runoff. If the rainfall intensity surpasses the soil infiltration rate or the rainfall is higher than the precipitation threshold, it can generate runoff. To investigate the relationship between precipitation and runoff, we used the cumulative curve method proposed by Hurst [35]. This method is based on the residual analysis and double mass curves (RA-DMC). The process is carried out in two steps. First, the consistency of annual precipitation and annual runoff is studied by using RA-DMC. Based on the discrete series of annual precipitation $P_{i}$ (mm) and annual runoff $R_{i}(\mathrm{~mm})$, the cumulative precipitation $X_{t}(\mathrm{~mm})$ and cumulative runoff $Y_{t}(\mathrm{~mm})$ can be expressed as follows:

$$
\begin{aligned}
& X_{t}=\sum_{i=1}^{t} P_{i} t=1,2, \ldots, n \\
& Y_{t}=\sum_{i=1}^{t} R_{i} t=1,2, \ldots, n
\end{aligned}
$$

where the length of the time series is denoted by $t$. The double mass curve is made by defining the cumulative precipitation as the independent variable and the cumulative runoff as the dependent variable. The investigation removed the runoff lags except for the first and final years.

Then, the relation between cumulative precipitation and cumulative runoff is investigated by linear regression. The following equations express definition:

$$
\begin{gathered}
Y_{t}=a+b X_{t} \quad t=1,2, \ldots, n \\
b=\frac{\sum_{t=1}^{n} X_{t} Y_{t}-n \bar{X} \bar{Y}}{\sum_{n=1}^{n} X_{t}^{2}-n \bar{X}^{2}}, \quad X=\frac{1}{n} \sum_{t=1}^{n} X_{t}, \quad Y=\frac{1}{n} \sum_{t=1}^{n} Y_{t} \\
a=\bar{Y}-b \bar{X}
\end{gathered}
$$

where the cumulated annual precipitation and the cumulated annual runoff are denoted by $\bar{X}$ and $\bar{Y}$, respectively, the changing extent of $Y_{t}$ according to the changes of $X_{t}$ is denoted by $b$. 


\subsection{VIC-3L Model}

In this paper, the three-layer Variable Infiltration Capacity (VIC-3L) model is used to quantify the relative contribution rates of climatic variability and human intervention to runoff change. The VIC-3L model divides the basin into sub-grids, and firstly simulates the independent runoff generation in each sub-grid according to water balance and energy balance principles and obtains the surface runoff and base flow based on grid units. Then, by using the routing model, the runoff components first converge to the grid boundary and then converge to the basin outlet through the river channel. The routing in the grid adopts the method of unit line, and the linear Saint-Venant equations reflect the river routing process. The specific model principles and calculation formulas can be referred to the official VIC model website (http: / / www.hydro.washington.edu/Lettenmaier/Models/ $\mathrm{VIC} /$, accessed on 10 September 2021).

The VIC-3L model was run at $0.0625^{\circ} \times 0.0625^{\circ}$ spatial resolution and daily temporal resolution. The hydrometeorological data are interpolated into each grid by the Inverse Distance Weighted (IDW) method. We select the hydrometeorological data from 1964 to 2015 for hydrological simulation. The VIC-3L model is driven by atmospheric forcing data (such as daily maximum temperature, minimum temperature, daily precipitation, sunshine hours, and daily average wind speed) and uses the observed runoff to calibrate the model.

The accuracy of VIC simulation is evaluated by the Nash-Sutcliffe Coefficient of Efficiency (NSCE) and BIAS, respectively. The specific calculation formulas are as follows:

$$
\begin{gathered}
N S C E=1-\frac{\sum_{i=1}^{n}\left(Q_{o b s, i}-Q_{s i m, i}\right)^{2}}{\sum_{i=1}^{n}\left(Q_{o b s, i}-\bar{Q}_{o b s}\right)^{2}} \\
B I A S=\frac{Q_{s i m, i}-Q_{o b s, i}}{\bar{Q}_{o b s}} \times 100 \%
\end{gathered}
$$

where $Q_{o b s, i}$ and $Q_{s i m, i}$ are the observed runoff $(\mathrm{mm} / \mathrm{month})$ and the simulated runoff $(\mathrm{mm} / \mathrm{month})$ at time step $i$, mean observed values $(\mathrm{mm} / \mathrm{month})$ is denoted as $\bar{Q}_{o b s}$, and the number of data points is denoted as $n$.

\subsection{Quantitative Analysis of the Effects of Climatic Variability and Human Intervention on Runoff}

Climatic variability and human intervention affect runoff. The impacts caused by human intervention are assumed to be independent of those caused by climatic variability in this research. Thus, the total change of runoff is defined as the following equation:

$$
\Delta Q_{t o t}=\Delta Q_{c v}+\Delta Q_{h a}
$$

where $\Delta Q_{\text {tot }}$ refers to the total change of runoff, $\Delta Q_{c v}$ refers to the runoff change caused by climatic variability, $\Delta Q_{h a}$ refers to the runoff change caused by human intervention.

To quantify the impacts of climatic variability and human intervention on runoff change, it is necessary to determine a baseline period. Under natural conditions (no interference from human intervention or weak interference from human intervention), the double cumulative curve of precipitation and runoff is a straight-line, which can be used as a baseline periodically affected by climatic variability solely. With the aggravation of human intervention and climatic variability (temperature rises and precipitation changes), the dependent variable of cumulative runoff is no longer only affected by precipitation, and the slope of cumulative hyperbola changes, resulting in change points. This study quantitatively analyzes climatic variability and human intervention that caused runoff change during the change period. Using the RA-DMC and VIC model, the annual runoff after the baseline period is reconstructed, and the total amount of runoff change in the basin can be expressed as follows:

$$
\Delta Q_{t o t}=\bar{Q}_{2}^{o b s}-\bar{Q}_{1}^{o b s}
$$

where $\bar{Q}_{1}^{o b s}$ and $\bar{Q}_{2}^{o b s}$ are the observed annual average runoff in the baseline period and the change period, respectively.

$$
\Delta Q_{c v}=\bar{Q}_{2}^{r e c}-\bar{Q}_{1}^{r e c}
$$


where $\bar{Q}_{1}^{r e c}$ and $\bar{Q}_{2}^{r e c}$ are the mean annual runoff after the reconstruction in the baseline period and the change period, respectively.

$$
\Delta Q_{h a}=\bar{Q}_{2}^{o b s}-\bar{Q}_{1}^{o b s}-\bar{Q}_{2}^{r e c}-\bar{Q}_{1}^{r e c}
$$

From the formula (9), it can be concluded that human intervention caused the difference between observed runoff and reconstructed runoff. According to formula (10) and formula (11), the relative influence rates of climatic variability $I_{c v}$ and human activity $I_{h a}$ on runoff change are shown as follows:

$$
\begin{aligned}
& I_{c v}=\frac{\Delta Q_{c v}}{\left|\Delta Q_{c v}\right|+\left|\Delta Q_{h a}\right|} \times 100 \% \\
& I_{h a}=\frac{\Delta Q_{h a}}{\left|\Delta Q_{c v}\right|+\left|\Delta Q_{h a}\right|} \times 100 \%
\end{aligned}
$$

\section{Results}

\subsection{Variations of Runoff in the Laohahe Basin}

Figure 2 and Table 2 show the time series of hydrometeorological characteristics (precipitation, potential evapotranspiration and runoff) and the results of the Mann-Kendall trend test in Laohahe Basin (Basin 4) from 1964 to 2015. The results show that the test statistics of the above hydrometeorology factors are $-1.27,-0.13$, and -4.88 . However, only the absolute $Z \alpha / 2$ of runoff is larger than 1.96 , indicating that the runoff change in the study area has reached a significant level. The annual precipitation decreased slightly with a $-7.03 \mathrm{~mm} / 10$ a change rate and a statistical index of -1.27 in the Mann-Kendall test. The decreasing trend of annual runoff is significant (test of significance less than 0.01), with a change rate of $-6.61 \mathrm{~mm} / 10 \mathrm{a}$ and a statistical index of -4.88 in the Mann-Kendall test. The trend of annual potential evapotranspiration is tiny. The runoff coefficient decreased from 0.09 in the 1960s to 0.01 in the 2010s (refer to Figure 2). It is obvious that the decrease of annual runoff in the Laohahe basin is more severe than that of annual precipitation. The annual precipitation in the 1980s is similar to that in the 2010s (about $390 \mathrm{~mm}$ ), while the annual runoff in these two periods is $16.0 \mathrm{~mm}$ and $3.53 \mathrm{~mm}$, so the observed runoff in the 2010s is less than that in the 1980s.

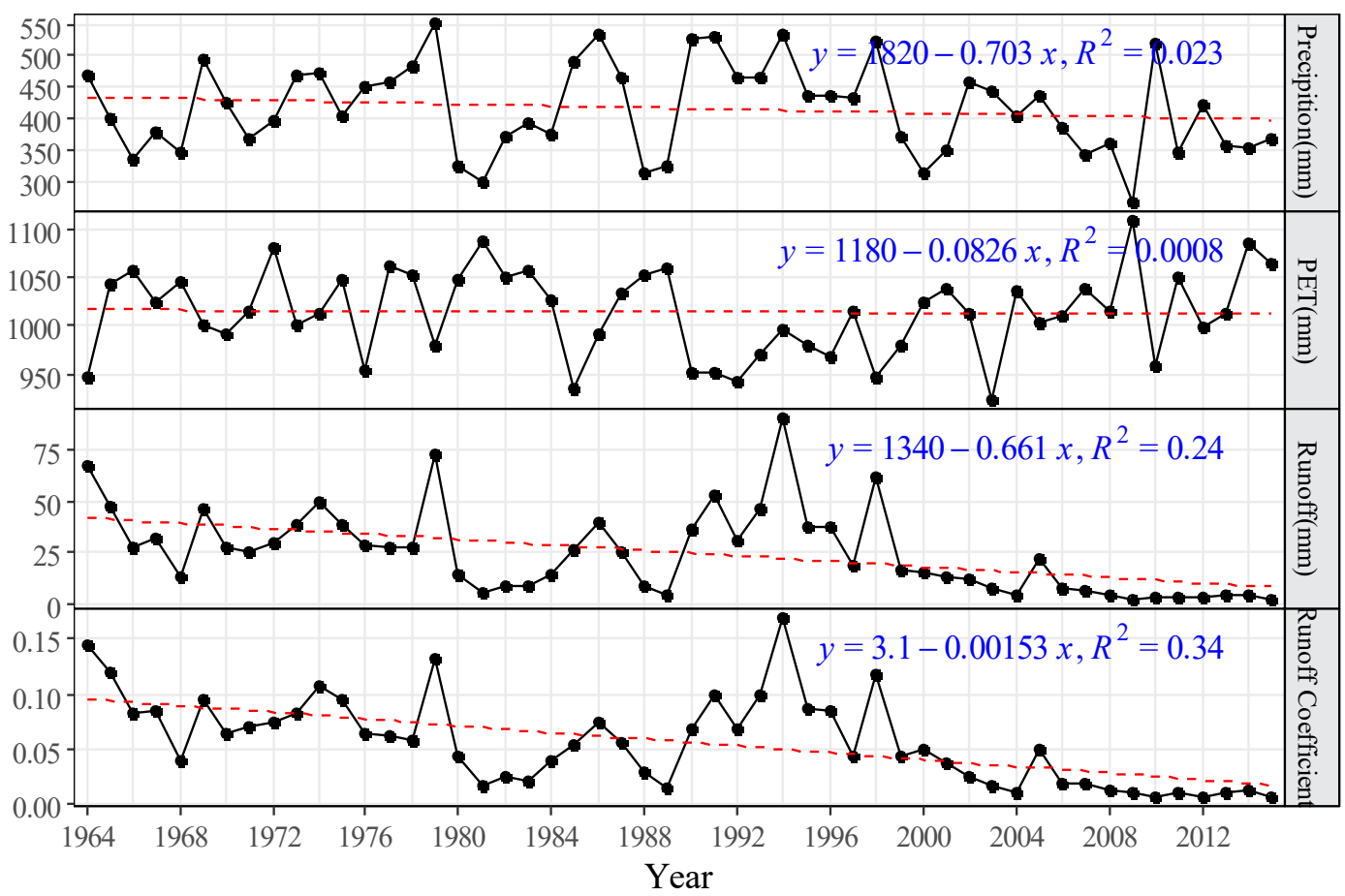

Figure 2. Time series of annual precipitation, PET (potential evapotranspiration), runoff, and runoff coefficient from 1964 to 2015 in the Laohahe basin. 
Table 2. Pettitt's and M-K trend tests P (precipitation), PET, and R (runoff) from 1964 to 2015 in Basin 1-4.

\begin{tabular}{|c|c|c|c|c|c|c|c|}
\hline \multirow{2}{*}{ Basin } & \multirow{2}{*}{ Variables } & \multirow{2}{*}{$\begin{array}{l}\text { Average Annual } \\
\text { Value (mm) }\end{array}$} & \multirow{2}{*}{$\begin{array}{c}\text { Change Ratio } \\
(\mathrm{mm} / 10 \mathrm{a})\end{array}$} & \multicolumn{3}{|c|}{ Mann-Kendall (MK) Trend Test } & \multirow{2}{*}{$\begin{array}{l}\text { Pettitt's Test for } \\
\text { Change Point (a) }\end{array}$} \\
\hline & & & & Test Statistics & Trends & Significance Level & \\
\hline \multirow{3}{*}{ 1. Dianzi } & $\mathrm{P}$ & 526.34 & -10.6 & -1.18 & $\downarrow$ & 0.24 & - \\
\hline & PET & 984.74 & -6.12 & -1.54 & $r$ & 0.12 & - \\
\hline & $\mathrm{R}$ & 63.1 & -12.8 & -2.66 & v & 0.008 & 1979,1998 \\
\hline \multirow{4}{*}{ 2. Chifeng } & $\mathrm{P}$ & 402.79 & -6.18 & -0.97 & $\downarrow$ & 0.33 & - \\
\hline & PET & 986.99 & 1.65 & 0.5 & | & 0.62 & - \\
\hline & $\mathrm{R}$ & 21.42 & -6.28 & -5.03 & | & $<0.001$ & 1979,1998 \\
\hline & $\mathrm{P}$ & 441.13 & -8.44 & -1.14 & & 0.25 & - \\
\hline \multirow{3}{*}{ 3. Taipingzhuang } & PET & 1028.83 & -4.32 & -1.28 & $\downarrow$ & 0.2 & - \\
\hline & $\mathrm{R}$ & 27.04 & -8.58 & -4.92 & t & $<0.001$ & 1979,1998 \\
\hline & $\mathrm{P}$ & 416.43 & -7.03 & -1.27 & $\downarrow$ & 0.2 & - \\
\hline \multirow{2}{*}{ 4. Laohahe } & PET & 1014.11 & -0.826 & -0.13 & $\downarrow$ & 0.89 & - \\
\hline & $\mathrm{R}$ & 25.24 & -6.61 & -4.88 & $\downarrow$ & $<0.001$ & 1979, 1998 \\
\hline
\end{tabular}

Similarly, the annual precipitation in the other three sub-basins shows downward trends consistently, but the changes are not significant ( $p$-value $>0.1$ ). The annual runoff all shows significant downward trends. The PET shows a weak (not significant) upward trend in the Chifeng basin, with other basins, have weak (not significant) downward PET trends.

Figure 3 shows that the double cumulative curves of runoff and precipitation in different basins from 1964 to 2015 . The relation between annual precipitation and runoff is unstable, strongly disturbed by human intervention and precipitation changes. The observed cumulative runoff curve recently dropped lower than the reconstructed runoff curve, expressing that the human intervention impacts runoff. All the four selected basins show two change points: 1979 and 1998. The change point in 1979 indicated that human intervention began to impact basin runoff, while the change point in 1998 suggested that the effect of human intervention on basin runoff was intensified. Pettitt's test shows that the annual PET and precipitation in the Laohahe Basin do not have change points. For runoff, two distinct change points (1979 and 1998) were found in all the basins. This result agreed well with Figure 3, which is based on the RA-DMC method. So, we determined that the baseline period is 1964-1979, and the change period is 1980-2015 in all the basins.

\subsection{Contribution of Climatic Variability and Human Intervention to the Runoff}

Trend analysis can only qualitatively describe the impact of climatic variability and human intervention on runoff, while the RA-DMC can be used to quantitatively calculate the impacts of precipitation and human intervention on runoff. From the above analyses, it can be seen that there is an obvious relationship between annual runoff and precipitation in the Laohahe basin in the past 52 years, and the influence of PET on runoff change is very weak. Therefore, the impacts of natural factors on runoff in the study area can be simplified to the impact of precipitation, while non-natural factors can be summarized as human intervention. The impacts of human intervention, including underlying surface change (land use and land cover change), pumping water from rivers and reservoirs for irrigation, residential and industrial water use, etc., can directly affect the runoff. Because the annual land use in the Laohahe basin is difficult to collect and some statistical data are not available, it is difficult to analyze the contributions of land use and land cover change. Therefore, this paper only discusses the contribution rate of the overall effect of human intervention on runoff change.

The regression prediction equation is obtained by establishing the regression relation of cumulative precipitation to cumulative runoff (Figure 3). Taking the Laohahe basin as an example, the mathematical formula of cumulative precipitation-runoff in the Laohahe basin is $Y=38.1+0.0779 x, R^{2}=1, p \leq 0.001$. The fitting degree of this equation is perfect. So, the cumulative runoff in the change period is reconstructed by using the regression equation. Other basins can also use this method to achieve reconstructed runoff during the change period.

The VIC model is used for quantitative analysis in the selected basins. Based on the above studies, we define 1964-1979 as the baseline period and 1980-2015 as the change period. 


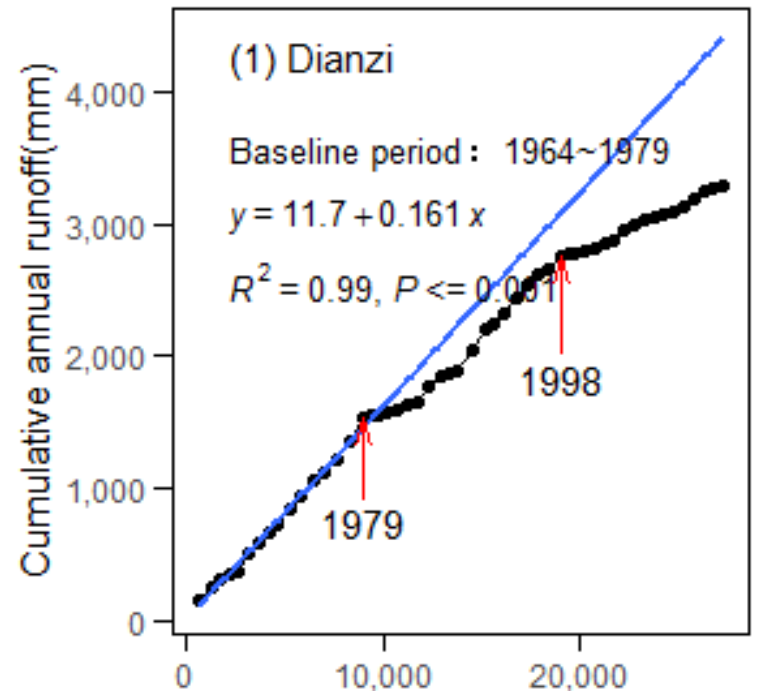

Cumulative annual precipitation $(\mathrm{mm})$

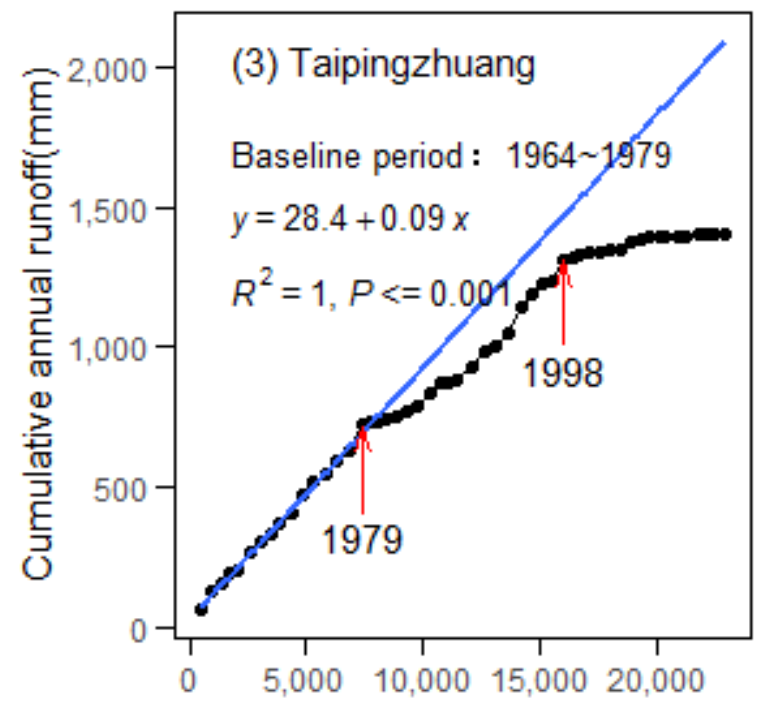

Cumulative annual precipitation(mm)

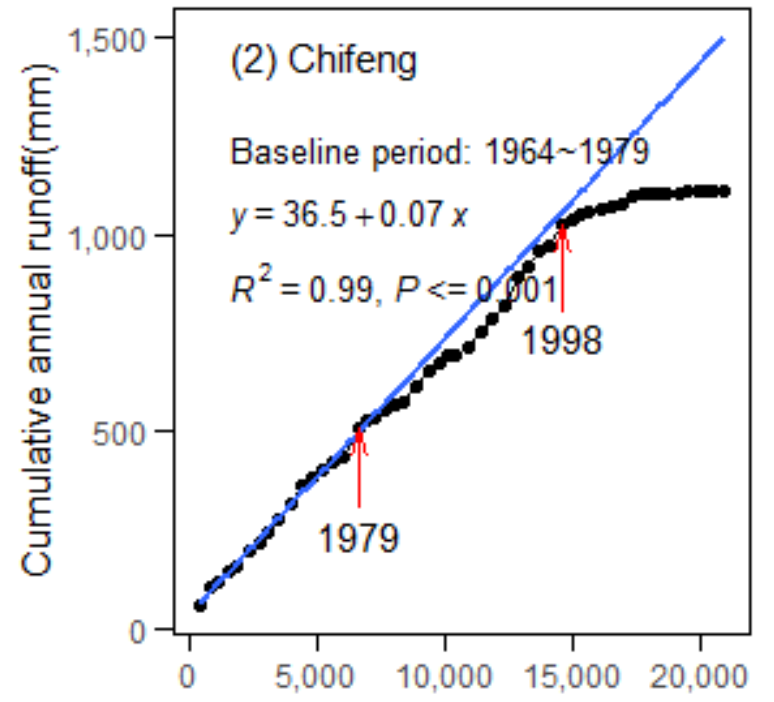

Cumulative annual precipitation(mm)

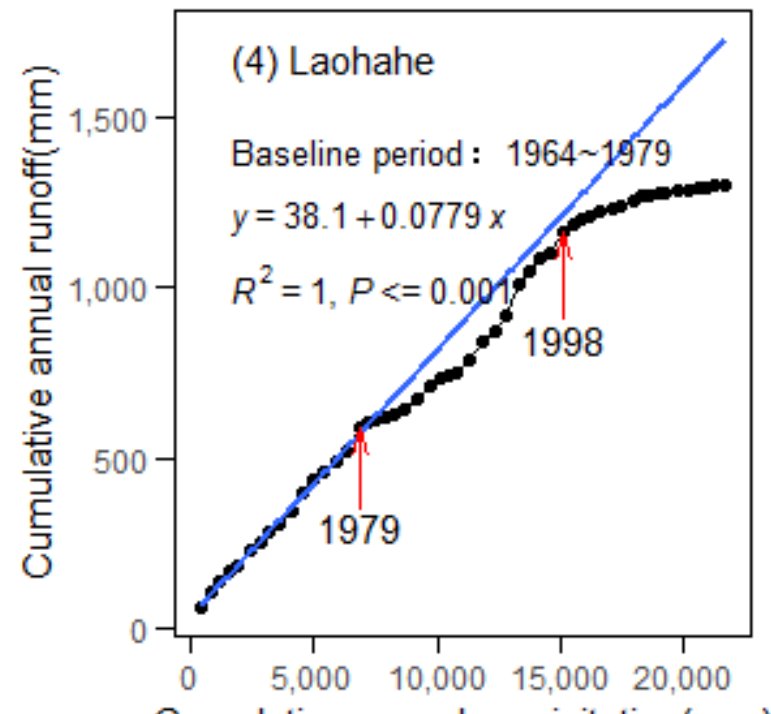

Cumulative annual precipitation $(\mathrm{mm})$

Figure 3. RA-DMC of runoff and precipitation in the four basins from 1964 to 2015 . The blue line indicates the linear regression of accumulated runoff and precipitation in the baseline period. The extended lines represent the reconstructed cumulative runoff during the change period.

Figure 4 shows the time series of monthly runoff simulated by the VIC model in the four basins (Basin 1-4). The VIC model performed well in the baseline period. The efficiency coefficient (NSCE) is between 0.72 and 0.88 , and the biases are less than $5 \%$, indicating that the VIC model can well reconstruct the historical hydrological process. The optimized parameters and statistical indicators of the VIC-3L model are listed in Table 3.

Table 3. The optimized parameters and statistical indicators of the VIC-3L model during the baseline period.

\begin{tabular}{|c|c|c|c|c|c|c|c|c|c|}
\hline \multirow{2}{*}{ Basin } & \multicolumn{7}{|c|}{ Parameter } & \multirow{2}{*}{ NSCE } & \multirow{2}{*}{ Bias $(\%)$} \\
\hline & $\mathbf{b}$ & $d_{2}$ & $\mathrm{D}_{\mathrm{s}}$ & $\mathrm{D}_{\mathrm{m}}$ & $\mathbf{W}_{\mathrm{s}}$ & $d_{1}$ & $d_{3}$ & & \\
\hline 1. Dianzi & 0.22 & 0.5 & 0.004 & 7 & 0.9 & 0.1 & 1.5 & 0.83 & 3.19 \\
\hline 2. Chifeng & 0.07 & 0.5 & 0.003 & 4 & 0.9 & 0.1 & 2 & 0.73 & -0.66 \\
\hline 3. Taipingzhuang & 0.055 & 0.55 & 0.004 & 4 & 0.9 & 0.1 & 2 & 0.82 & 0.28 \\
\hline 4. Laohahe & 0.1 & 0.55 & 0.004 & 10 & 0.8 & 0.1 & 2 & 0.81 & 3.47 \\
\hline
\end{tabular}



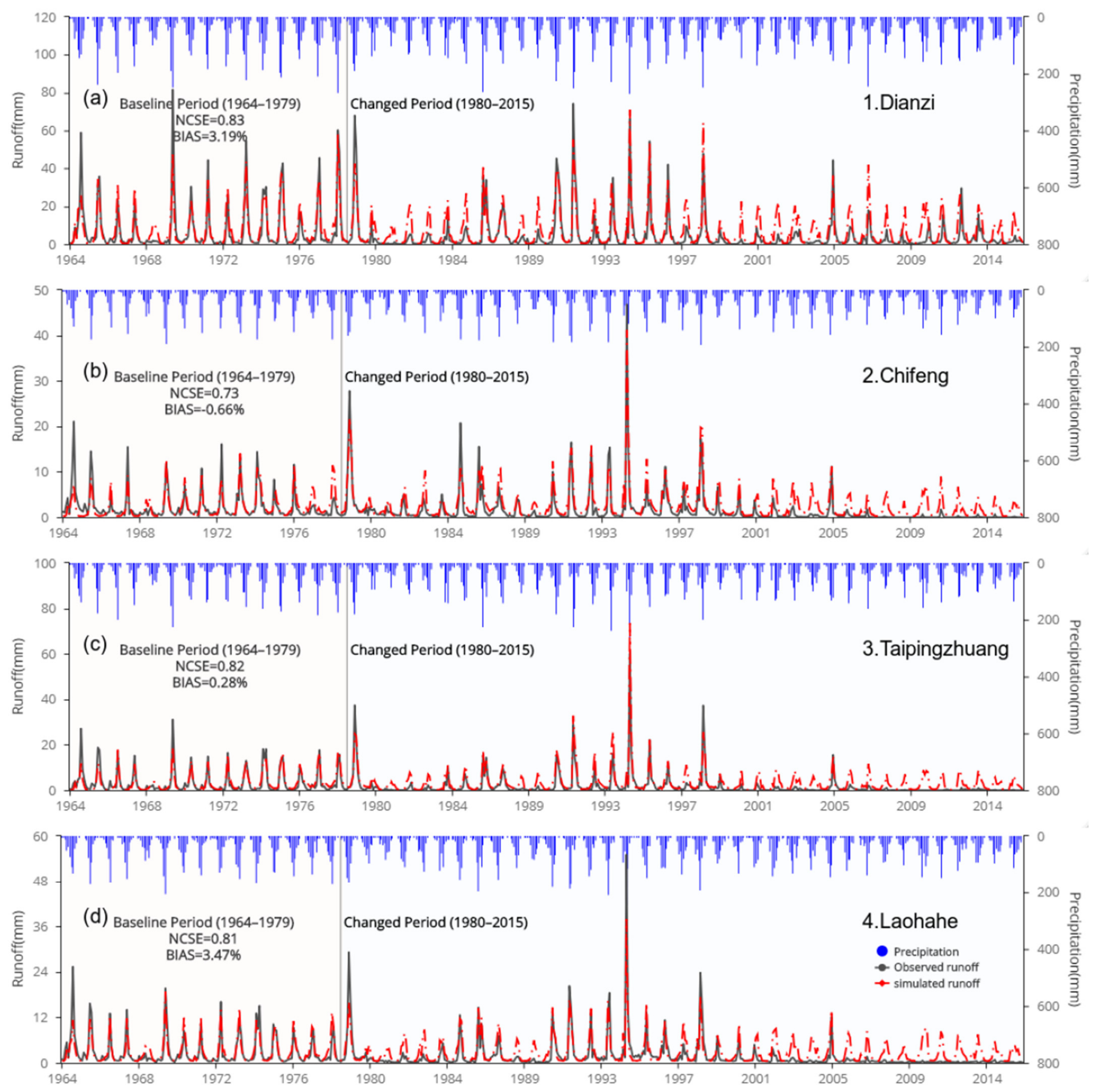

Figure 4. Monthly observed and simulated runoff (by VIC model) from 1964 to 2015 over the four selected basins: (a) Dianzi, (b) Chifeng, (c) Taipingzhuang, (d) Laohahe.

Based on the observed and reconstructed runoff, the impacts of climatic variability and human intervention can be quantitatively separated according to the conceptual framework proposed in the methods. The quantitative estimates of the interannual variation and change period by RA-DMC and VIC models are shown in Table 4 . The study shows that in the change period of all basins, the impact of human intervention on runoff change is greater than that of climatic variability. Taking the Laohahe basin as an example, the RA-DMC shows that human intervention in the Laohahe basin caused about $76.84 \%(-13.64 \mathrm{~mm})$ runoff reduction during the whole change period (1980-2015), while the contribution rate of precipitation factor to runoff reduction was only $23.16 \%(-4.11 \mathrm{~mm})$. In all periods, except in the 1990s, precipitation changes and human intervention negatively affected runoff, 
indicating that precipitation changes and human intervention reduced runoff. Among them, human intervention played a leading role in runoff reduction $(74.12 \%$ in the $1980 \mathrm{~s}$, $74.71 \%$ in the $2000 \mathrm{~s}, 84.76 \%$ in $2010-2015$ ), and the effect of human intervention on runoff gradually increased from 2010 to 2015 . The contribution rates of climatic variability and human intervention simulated by the VIC model in the 1980s, 1990s, 2000s and 2010-2015 were $-26.06 \%, 84.96 \%,-26.07 \%,-16.53 \%$ and $-73.94 \%,-15.04 \%,-73.93 \%,-83.47 \%$, respectively. The VIC model shows that climatic variability in the 1990s was the dominant driver, while human activities in other periods were stronger. The relative contribution rates based on the two methods are similar.

Table 4. Effects of climatic variability and human intervention on mean annual runoff using RA-DMC and VIC model.

\begin{tabular}{|c|c|c|c|c|c|c|c|c|c|c|}
\hline \multirow{3}{*}{ Basin } & \multirow{3}{*}{ Duration } & \multirow{3}{*}{$\Delta Q_{t o t}(\mathrm{~mm} / \mathrm{a})$} & \multicolumn{4}{|c|}{ RA-DMC } & \multicolumn{4}{|c|}{ VIC Model } \\
\hline & & & \multicolumn{2}{|c|}{$\Delta Q_{c v}$} & \multicolumn{2}{|c|}{$\Delta Q_{h a}$} & \multicolumn{2}{|c|}{$\Delta Q_{c v}$} & \multicolumn{2}{|c|}{$\Delta Q_{h a}$} \\
\hline & & & $\mathrm{mm} / \mathrm{a}$ & $\%$ & $\mathrm{~mm} / \mathrm{a}$ & $\%$ & $\mathrm{~mm} / \mathrm{a}$ & $\%$ & $\mathrm{~mm} / \mathrm{a}$ & $\%$ \\
\hline 1. Dianzi & $\begin{array}{l}1980-1989 \\
1990-1999 \\
2000-2009 \\
2010-2015 \\
1980-2015\end{array}$ & $\begin{array}{c}-58.64 \\
-7.56 \\
-65.81 \\
-60.5 \\
-46.75\end{array}$ & $\begin{array}{l}-13.55 \\
-0.03 \\
-13.43 \\
-8.59 \\
-8.93\end{array}$ & $\begin{array}{c}-23.1 \\
-0.39 \\
-20.4 \\
-14.2 \\
-19.11\end{array}$ & $\begin{array}{l}-45.1 \\
-7.53 \\
-52.38 \\
-51.91 \\
-37.82\end{array}$ & $\begin{array}{c}-76.9 \\
-99.61 \\
-79.6 \\
-85.8 \\
-80.89\end{array}$ & $\begin{array}{l}-25.03 \\
7.34 \\
-24.82 \\
-19.32 \\
-15.03\end{array}$ & $\begin{array}{c}-42.69 \\
33 \\
-37.72 \\
-31.94 \\
-32.15\end{array}$ & $\begin{array}{c}-33.61 \\
-14.9 \\
-40.98 \\
-41.18 \\
-31.72\end{array}$ & $\begin{array}{c}-57.31 \\
-67 \\
-62.28 \\
-68.06 \\
-67.85\end{array}$ \\
\hline 2. Chifeng & $\begin{array}{l}1980-1989 \\
1990-1999 \\
2000-2009 \\
2010-2015 \\
1980-2015\end{array}$ & $\begin{array}{l}-13.33 \\
2.35 \\
-25.13 \\
-30.95 \\
-15.19\end{array}$ & $\begin{array}{c}-4.33 \\
0.98 \\
-5.73 \\
-4.61 \\
-3.29\end{array}$ & $\begin{array}{c}-32.45 \\
41.74 \\
-22.8 \\
-14.9 \\
-21.65\end{array}$ & $\begin{array}{c}-9.01 \\
1.37 \\
-19.4 \\
-26.34 \\
-11.9\end{array}$ & $\begin{array}{l}-67.55 \\
58.26 \\
-77.2 \\
-85.1 \\
-78.35\end{array}$ & $\begin{array}{c}-3.71 \\
15.5 \\
-8.18 \\
-10 \\
-0.66\end{array}$ & $\begin{array}{c}-27.79 \\
54.11 \\
-32.56 \\
-32.29 \\
-4.36\end{array}$ & $\begin{array}{l}-9.63 \\
-13.15 \\
-16.95 \\
-20.96 \\
-14.53\end{array}$ & $\begin{array}{l}-72.21 \\
-45.89 \\
-67.44 \\
-67.71 \\
-95.64\end{array}$ \\
\hline 3. Taipingzhuang & $\begin{array}{l}1980-1989 \\
1990-1999 \\
2000-2009 \\
2010-2015 \\
1980-2015\end{array}$ & $\begin{array}{l}-28.97 \\
-0.63 \\
-37.6 \\
-43.35 \\
-25.89\end{array}$ & $\begin{array}{c}-7 \\
0.97 \\
-7.5 \\
-5.78 \\
-4.72\end{array}$ & $\begin{array}{l}-24.17 \\
37.69 \\
-19.96 \\
-13.34 \\
-18.24\end{array}$ & $\begin{array}{c}-21.96 \\
-1.61 \\
-30.1 \\
-37.57 \\
-21.17\end{array}$ & $\begin{array}{l}-75.83 \\
-62.31 \\
-80.04 \\
-86.66 \\
-81.76\end{array}$ & $\begin{array}{c}-13.68 \\
16.86 \\
-15.04 \\
-13.51 \\
-5.55\end{array}$ & $\begin{array}{c}-47.23 \\
49.08 \\
-39.99 \\
-31.17 \\
-21.42\end{array}$ & $\begin{array}{l}-15.29 \\
-17.49 \\
-22.57 \\
-29.84 \\
-20.35\end{array}$ & $\begin{array}{l}-52.77 \\
-50.92 \\
-60.01 \\
-68.83 \\
-78.58\end{array}$ \\
\hline 4. Laohahe & $\begin{array}{l}1980-1989 \\
1990-1999 \\
2000-2009 \\
2010-2015 \\
1980-2015\end{array}$ & $\begin{array}{c}-21.84 \\
5.18 \\
-26.69 \\
-34.26 \\
-17.76\end{array}$ & $\begin{array}{c}-5.65 \\
0.73 \\
-6.75 \\
-5.22 \\
-4.11\end{array}$ & $\begin{array}{c}-25.88 \\
14.16 \\
-25.29 \\
-15.24 \\
-23.16\end{array}$ & $\begin{array}{c}-16.19 \\
4.45 \\
-19.94 \\
-29.04 \\
-13.64\end{array}$ & $\begin{array}{c}-74.12 \\
85.84 \\
-74.71 \\
-84.76 \\
-76.84\end{array}$ & $\begin{array}{c}-5.69 \\
6.29 \\
-6.96 \\
-5.66 \\
-2.71\end{array}$ & $\begin{array}{c}-26.06 \\
84.96 \\
-26.07 \\
-16.53 \\
-15.27\end{array}$ & $\begin{array}{c}-16.15 \\
-1.11 \\
-19.74 \\
-28.6 \\
-15.04\end{array}$ & $\begin{array}{l}-73.94 \\
-15.04 \\
-73.93 \\
-83.47 \\
-84.73\end{array}$ \\
\hline
\end{tabular}

For the Dianzi basin, the RA-DMC shows that human intervention contributed $80.89 \%$ $(-37.82 \mathrm{~mm})$ and the change of precipitation contributed $19.11 \%$ to the decrease of runoff during the whole change period, indicating that human intervention played a leading role. In the 1990s, climatic variability and human intervention contributed the least to runoff reduction $(-7.56 \mathrm{~mm})$ than the other periods. Precipitation only contributed $0.39 \%$ $(-0.03 \mathrm{~mm})$ to runoff reduction. In this period, human intervention contributed the most to runoff reduction $(99.61 \%)$. Excluding the 1990s, the impact of human intervention on runoff increased, reaching the maximum (85.8\%) in 2010-2015. The contribution rates of climatic variability and human intervention simulated by the VIC model in the 1980s, 1990s, 2000s and $2010-2010$ were $-42.69 \%, 33 \%,-37.72 \%,-31.94 \%$ and $-57.31 \%,-67 \%,-62.28 \%$, $-68.06 \%$, respectively. The Dianzi basin is relatively affected by climatic variability, and the contribution rate of climatic variability to runoff decreases year by year. At the same time, although the influence of human intervention is still dominant, the contribution rates are less than $70 \%$.

In the Chifeng basin, the RA-DMC shows that human intervention contributed $78.35 \%$ $(-11.9 \mathrm{~mm})$, and the change of precipitation contributed $21.65 \%$ to the decrease of runoff during the whole change period, indicating that human intervention was the dominant factor in the Chifeng basin. Precipitation changes and human intervention only increased runoff in the 1990s, and human intervention was the dominant factor (58.26\%). In other periods, precipitation change and human intervention negatively affected runoff, and human intervention played a dominant role $(67.55 \%$ in the $1980 \mathrm{~s}, 77.2 \%$ in the $2000 \mathrm{~s}$, and $85.1 \%$ in 2010-2015), indicating that it had an increasing impact on the basin. The contribution rates of climatic variability and human intervention simulated by the VIC model to runoff in the 1980s, 1990s, 2000s and 2010-2010 were $-27.79 \%, 54.11 \%,-32.56 \%,-32.29 \%$ and $-72.21 \%,-45.89 \%,-67.44 \%,-67.71 \%$. The changing trend by the RA-DMC is similar to 
the Dianzi basin, but the contribution rate of human intervention to runoff is less than $75 \%$, which also indicates that the Chifeng basin is greatly affected by temperature, evaporation, and other climatic factors, but the RA-DMC does not consider these climatic factors. In the Taipingzhuang basin, the RA-DMC shows that human intervention contributed $81.76 \%$ $(-21.17 \mathrm{~mm})$ and the change of precipitation contributed $18.24 \%(-4.72 \mathrm{~mm})$ to the decrease of runoff during the whole change period, and human intervention played a leading role in the whole change period. From the perspective of time, human intervention has reduced the runoff at all periods, which is the main driving factor of runoff reduction. In the 1990s, the human intervention had the least impact on runoff, accounting for $62.31 \%$, and contributed the most to runoff reduction from 2010 to 2015, reaching 86.66\%. Precipitation change had a positive effect on runoff in the 1990s, with a contribution rate of $37.69 \%$ to runoff increase. It had negative effects on runoff, with the largest contribution rate to runoff decrease in the 1980s (24.17\%). The contribution rates of climatic variability and human intervention simulated by VIC model to runoff in the 1980s, 1990s, 2000s and 2010-2010 were $-47.23 \%, 49.08 \%,-39.99 \%,-31.17 \%$ and $-52.77 \%,-50.92 \%,-60.01 \%,-68.83 \%$. Based on the VIC simulated runoff, climatic variability played a similar role with human intervention in the 1980s and 1990s. The contribution rate of climatic variability decreased after the 1990s, while the contribution rate of human intervention increased.

Based on the assessment of the interdecadal variation of runoff in Table 4, we further observed that human intervention in the dry period had a greater impact on runoff reduction than those in the wet period. Taking the Laohahe basin as an example, human intervention accounted for $-15.04 \%$ in the 1990 s when there was more precipitation, and $-73.94 \%,-73.94 \%$, and $-83.47 \%$ in the 1980s, 2000s, and 2010-2015 when there was less precipitation when using the VIC model. In addition, in the 1990s, the RA-DMC showed that human intervention positively influenced runoff changes in the Chifeng and Laohahe river basins, which did not occur in the years with less precipitation. The results show that when precipitation is low, more water will be extracted from river channels for agricultural and industrial usage, which will further reduce runoff. On the contrary, in the humid period, due to less human intervention, the impacts of human activities on runoff are relatively small.

For the Dianzi, Chifeng, and Taipingzhuang basin, when the VIC model is used, the relative contribution rate of human intervention to runoff is higher than that of RA_DMC. This is because the RA_DMC method is mainly used to separate the hydrological effect of precipitation and non-precipitation element. Thus, the contribution rate from human intervention is overrated, and the contribution rate from climatic variability is underrated when the separation was made. The previous analyses show that runoff variation is decisively affected by precipitation, and PET scarcely affects runoff. The potential effect from PET can hardly be contained in this study. Thus, the present research can determine the possible contribution rate as the estimated effect of human intervention on the runoff. Nevertheless, the PET fluctuation is generally limited in a short time, while precipitation and other human intervention have a distinctly more significant impact on runoff. At the same time, the VIC model parameter calibration, structures and scale problems may lead to many uncertainties in the results. Thus, the study can obtain rigorous evaluation results and be valuable for reference.

\section{Discussion}

\subsection{The Impact of Climatic Variability on Runoff}

Table 5 shows the mean annual PET, precipitation, and runoff changes during different change periods in the four basins compared to the baseline period. Taking the Laohahe basin (Basin 4) as an example, in the 1980s, 2000s, and 2010-2015, the precipitation compared with the baseline period decreased by $9.7 \%, 13 \%$, and $8.5 \%$, respectively. The change of PET is not obvious, while the runoff is reduced by $56.9 \%, 70 \%$, and $90.4 \%$, respectively compared with the baseline period. For the 2000s and 2010s, as the impact of climate factors on runoff decreases, it shows that the impact of human intervention is increasing. In the 
1990 s, the precipitation increased by $9.3 \%$, PET decreased by $4.8 \%$, and runoff increased by $16.2 \%$ compared with the baseline period.

Table 5. The mean annual PET, precipitation, and runoff changes during different durations of the four basins in the Laohaha basin compared to the baseline period.

\begin{tabular}{|c|c|c|c|c|c|c|c|c|c|c|c|c|}
\hline \multirow{2}{*}{ Basin } & \multicolumn{3}{|c|}{ 1980s Change (\%) } & \multicolumn{3}{|c|}{ 1990s Change (\%) } & \multicolumn{3}{|c|}{ 2000s Change (\%) } & \multicolumn{3}{|c|}{ 2010s Change (\%) } \\
\hline & $\mathbf{P}$ & PET & $\mathbf{R}$ & $\mathbf{P}$ & PET & $\mathbf{R}$ & $\mathbf{P}$ & PET & $\mathbf{R}$ & $\mathbf{P}$ & PET & $\mathbf{R}$ \\
\hline 1. Dianzi & -14.2 & -1.6 & -61.4 & 0.8 & -6.6 & -7.9 & -14.0 & -2.1 & -68.9 & -8.7 & -1.4 & -63.4 \\
\hline 2. Chifeng & -7.1 & 2.1 & -41.8 & 11.3 & -4.3 & 7.4 & -11.9 & 1.4 & -78.7 & -8.1 & 1.4 & -96.9 \\
\hline 3. Taipingzhuang & -12.5 & 0.1 & -64.4 & 6.6 & -5.5 & -1.4 & -13.7 & -1.5 & -83.6 & -9.6 & -0.3 & -96.4 \\
\hline 4. Laohahe & -9.7 & 1.5 & -56.9 & 9.3 & -4.8 & 16.2 & -13.0 & 0.1 & -70.0 & -8.5 & 0.8 & -90.4 \\
\hline
\end{tabular}

\subsection{The Impact of Human Intervention on Runoff}

Since the 1960s, the dramatic change of runoff in the Laohahe basin is influenced by climatic variability and human intervention. The main modes of production in the Laohahe basin are agriculture and animal husbandry. Land use and land cover change (LUCC) is mainly influenced by the policies issued by the national and regional governments. All these human interventions significantly altered LUCC and further affected the hydrological processes. Then we analyzed the conversion of LUCC based on four periods of remote sensing data from 1976, 1989, 1999, and 2006 (Figure 5). The results show that since 1976, forest, grassland, and cropland have been the mainland-use types in the Laohahe basin. In the Laohahe basin, the scale and range of land type transfer were large. Grassland area decreased year by year $(41.91 \%,-38.24 \%,-28.3 \%,-22.43 \%)$, while forest area decreased first and then increased $(33.78 \%,-19.4 \%,-31.34 \%,-32.04 \%)$. The total area of cropland showed an increasing trend $(21.05 \%,-38.76 \%,-37.23 \%,-41.75 \%)$.

Figure 6 and Table 6 show the Sankey diagram, area, and proportion of land use in different periods in the Laohahe basin. From 1976 to 1989, the area of cropland increased by $17.75 \%$ and the relative growth rate reached $84.3 \%$. The unused land increased by $0.89 \%$, the area of forest, grassland, and water bodies decreased by $14.38 \%, 3.71 \%$, and $0.45 \%$ respectively. The relative reduction rate of water bodies reached $60 \%$. The characteristics of LUCC during this period is the rapid expansion of cropland, which is mainly converted from forest and grassland. From 1989 to 1999, forest area and urban built area increased by $0.94 \%$ and $11.94 \%$, respectively, with a relative growth rate of $78.3 \%$ and $61.5 \%$. The area of cropland, grassland, and unused land decreased by $1.57 \%, 9.9 \%$, and $1.39 \%$, respectively. The relative reduction rates of grassland and unused lands were $25.9 \%$ and $66.1 \%$, respectively. LUCC in this period was characterized by the remarkable increase of forest, which is mainly from cropland. Grassland has been remarkably reduced. Nearly $50 \%$ of grassland was converted to cropland. The cropland area changed little, but the transfer scale and conversion range of cropland were extensive. Almost $60 \%$ of the cropland was converted to forest and grassland, while nearly $50 \%$ of the grassland was converted to cropland. The urban built continued to increase, while the water bodies area did not change remarkably. From 1999 to 2007, cropland and unused land increased by $4.52 \%$ and $0.23 \%$, respectively, while grassland decreased by $5.87 \%$. The characteristics of LUCC in this period were that the cropland increased slightly, mainly from grassland and forest. Grassland continued to decline, and a large amount of grassland was converted to forest and cropland. Forestland and water bodies area changed little, while construction land and unused land continued to increase. 

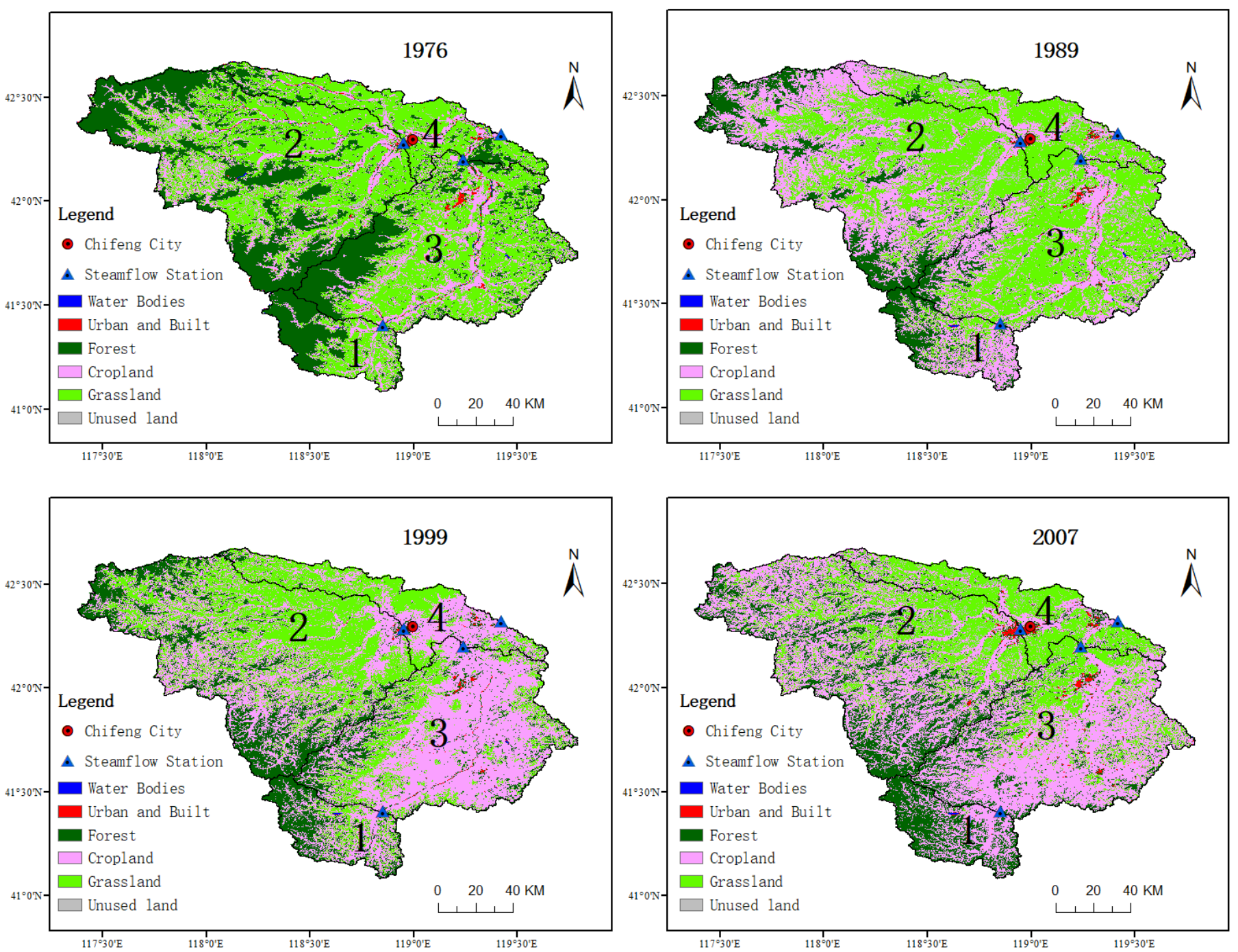

Figure 5. Spatial distribution of land use in 1976, 1989, 1999, and 2007 in Laohahe basin. The maps are classified as forest, grassland, water bodies, unused land, cropland, and urban and built.

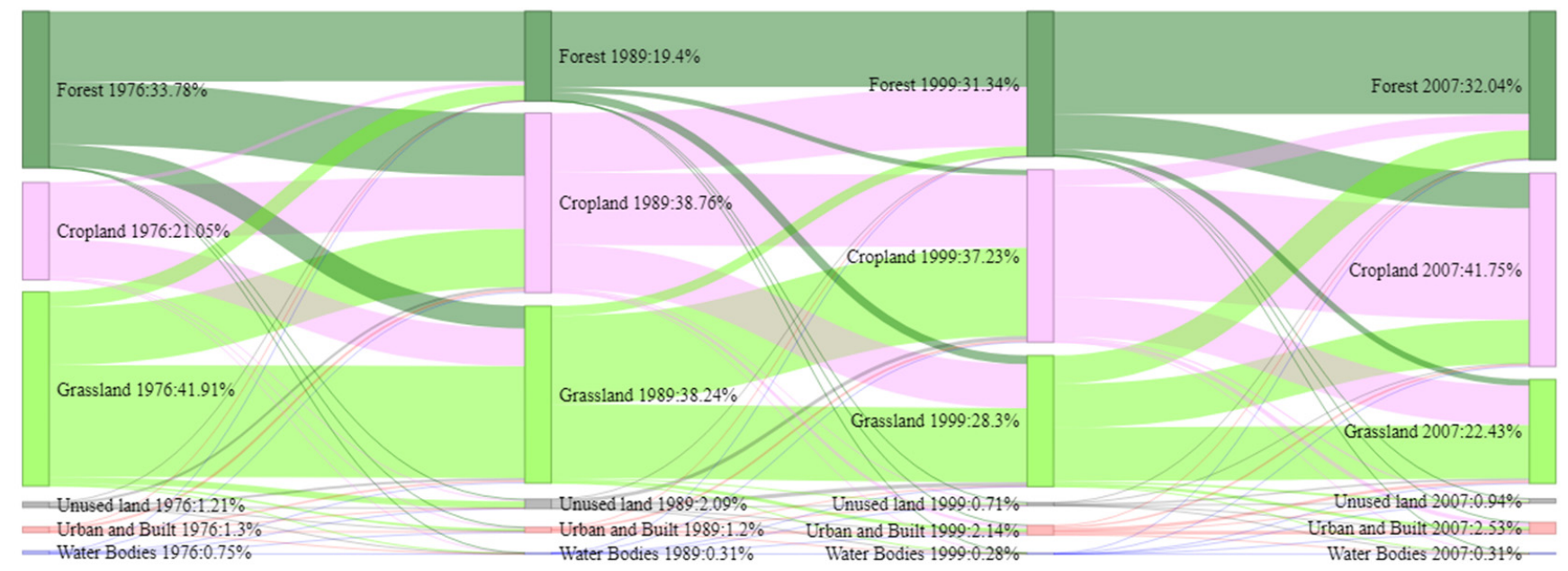

Figure 6. Sankey diagram of land use during 1976-1989-1999-2007 in the Laohahe basin. 
Table 6. Area and proportion of land use from 1976-1989-1999-2007 in the Laohahe basin.

\begin{tabular}{|c|c|c|c|c|c|c|c|c|}
\hline \multirow{2}{*}{ Land Use } & \multicolumn{2}{|c|}{1976} & \multicolumn{2}{|c|}{1989} & \multicolumn{2}{|c|}{1999} & \multicolumn{2}{|c|}{2007} \\
\hline & Area $/ \mathrm{km}^{2}$ & Rate/\% & Area/km² & Rate/\% & Area $/ \mathrm{km}^{2}$ & Rate/\% & Area/km² & Rate/\% \\
\hline Water Bodies & 134.94 & 0.75 & 55.85 & 0.3 & 50.11 & 0.28 & 55.57 & 0.31 \\
\hline Urban Built & 235.98 & 1.3 & 216.63 & 1.2 & 388.21 & 2.14 & 458.13 & 2.53 \\
\hline Forest & 6117.53 & 33.78 & 3514.13 & 19.4 & 5675.72 & 31.34 & 5803.51 & 32.04 \\
\hline Cropland & 3812.97 & 21.05 & 7020.9 & 38.8 & 6743.82 & 37.23 & 7561.43 & 41.75 \\
\hline Grassland & 7591.3 & 41.91 & 6926.6 & 38.2 & 5125.13 & 28.3 & 4062.98 & 22.43 \\
\hline Unused land & 219.28 & 1.21 & 377.88 & 2.1 & 129.01 & 0.71 & 170.38 & 0.94 \\
\hline
\end{tabular}

Generally speaking, since 1976, the grassland area of the basin has shown a decreasing trend, while cropland and urban built have shown an increasing trend, which also shows the transformation of the river basin from animal husbandry to an agricultural lifestyle. Regional and national development policies are the main driving forces of LUCC in the Laohahe basin. Since 1964, the government has encouraged human beings to develop agriculture and reclaim land to solve the food shortage problem. Therefore, cropland in the lower-middle reaches of the Laohahe River has become the primary type of land use. In the late 1990s, the government revised the public policy, encouraging farmers to return the cropland into the forest. Therefore, the cropland area decreased by $277 \mathrm{~km}^{2}$ in 1999 , while the forest area increased rapidly to $5803 \mathrm{~km}^{2}$ in 2007 , with a relative increase rate of $78.3 \%$ compared with 1989 . In addition, the grassland area shows a downward trend, which dropped from $6926 \mathrm{~km}^{2}$ in 1989 to $5125 \mathrm{~km}^{2}$ in 1999, because based on the agricultural policy at that time, even if they can return the cropland to grassland (instead of the forest), much fewer fiscal subsidies can be provided to the local farmers for the cropland abandonment. The land-use patterns, water resources, and the surface cover in the Laohahe basin have been turned by the superposition of these human interventions; and these human interventions further caused the hydrological system changes and responses.

Figure 7 shows that the economic and social data of Chifeng City have increased rapidly since 1964. For instance, the population of Chifeng City was only 2.54 million in 1964, and it grew to 4.52 million in 2000. After entering the 21st century, the population growth began to slow down and even declined slightly. Till 2016, the population of Chifeng City dropped to 4.3 million, while GDP exhibited exponential growth. The population, food, and livestock declined sharply from the end of the 1990s to the beginning of the 21st century. This phenomenon was closely related to the migrant workers' working tide. Many farmers left the rural residence (the population growth trend suddenly declined) and went to work in more developed cities. Therefore, it can be seen that although the production capacity decreased, the growth of local agriculture and industry recovered rapidly after the 2000s. In addition to irrigation water and economic development water, new reservoirs and dams may be another factor that leads to a sharp drop in the runoff.

Table 7 shows the characteristics and construction information of three major reservoirs in the Laohahe basin. San Zuodian Reservoir was built in 2003-2005 with a storage capacity of 369 million $\mathrm{m}^{3}$, which caused a dramatic decrease in observed streamflow after 2003. The total storage capacity of all the reservoirs in the Laohahe basin is 500 million $\mathrm{m}^{3}$. These reservoirs and ponds provide more water supply for domestic usage and irrigation. However, it also changes the natural hydrological cycle of the Laohahe basin. 

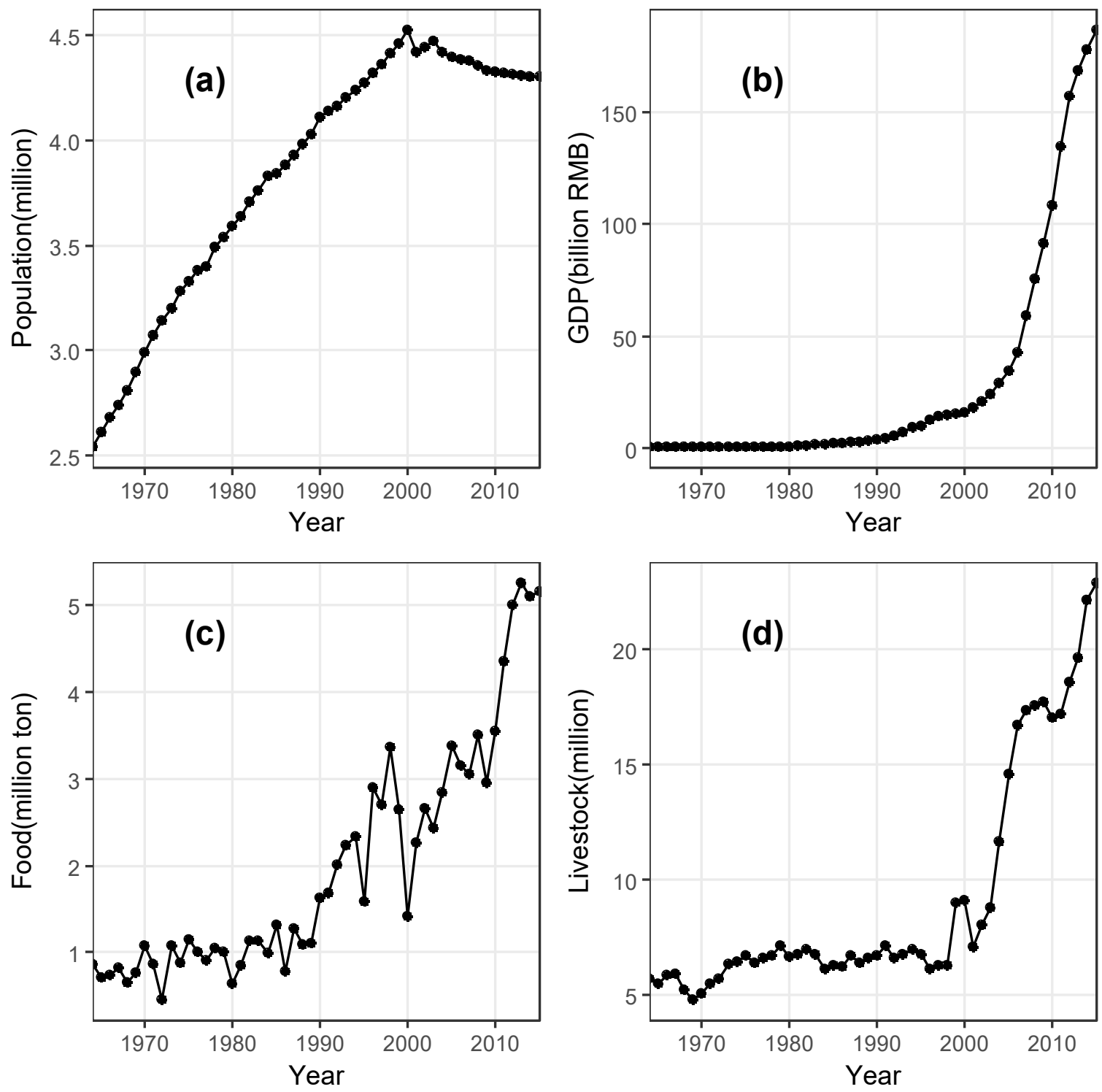

Figure 7. Changes in GDP, population, food, and livestock in Chifeng City for 1964-2015, (a) population; (b) GDP; (c) Food; (d) Livestock.

Table 7. Introduction to the construction of large reservoirs in the Laohahe basin.

\begin{tabular}{cccccc}
\hline Reservoir & Lat/Lon of the Reservoir's Dam & River & Building Time (year) & Storage Capacity $\left(\mathbf{1 0 ^ { 8 }} \mathbf{m}^{\mathbf{3}}\right)$ & Class $^{\prime}$ \\
\hline San Zuodian & $42^{\circ} 14^{\prime} \mathrm{N}, 118^{\circ} 54^{\prime} \mathrm{E}$ & Yin & $2003-2005$ & 3.69 & II \\
Erdao Heai & $42^{\circ} 18^{\prime} \mathrm{N}, 119^{\circ} 00^{\prime} \mathrm{E}$ & Xiluga & $1968-1971$ & 1.8 & III \\
Da Hushi & $41^{\circ} 25^{\prime} \mathrm{N}, 118^{\circ} 41^{\prime} \mathrm{E}$ & Heili & $1968-1970$ & II \\
\hline
\end{tabular}

Figure 8 and Table 8 show the distribution of soil erosion intensity and slope zone. It can be seen that the soil erosion in the Laohahe basin is mainly caused by water erosion (>98\%), and very little by wind erosion (northwest corner of the basin, $<2 \%$ ). Among them, slight, mild, and moderate water erosion accounts for $45.64 \%, 24.67 \%$, and $20.54 \%$ of the whole basin, respectively, indicating that more than $90 \%$ of the basin has moderate or less soil erosion. This part of the erosion area is mainly distributed in the plains along the river, the upper reaches of the basin, and the Taipingzhuang basin, which coincides with the region's flat terrain. Intensive and extreme erosion areas account for $7.36 \%$ and $0.18 \%$ of the total erosion area, respectively, are mainly distributed in the hilly valley of the middle and upper reaches of the basin, the middle of the Chifeng basin, and other sporadic areas with a steep slope. Based on Table 8 , the slope zone of $<3^{\circ}$ has the largest erosion area, 
with an area of $5477 \mathrm{~km}^{2}$, accounting for $29.2 \%$ of the total erosion area, followed by the slope zones of $8^{\circ} \sim 15^{\circ}, 5^{\circ} \sim 8^{\circ}, 3^{\circ} \sim 5^{\circ}$, and $15^{\circ} \sim 25^{\circ}$, account for $26.93 \%, 16.38 \%, 13.77 \%$, and $13.18 \%$, respectively. Based on the distribution of erosion intensity, slight erosion is mainly concentrated in the slope zone of $<3^{\circ}$, mild, moderate, intensive, and extreme erosion is primarily concentrated in the slope zone of $8^{\circ} \sim 15^{\circ}$; it can be seen that the area of the slope below $15^{\circ}$ is the main area of soil erosion, followed by the area of slope between $15^{\circ}$ and $25^{\circ}$; therefore, land resource management and soil erosion control should be strengthened in the slope zone below $25^{\circ}$.
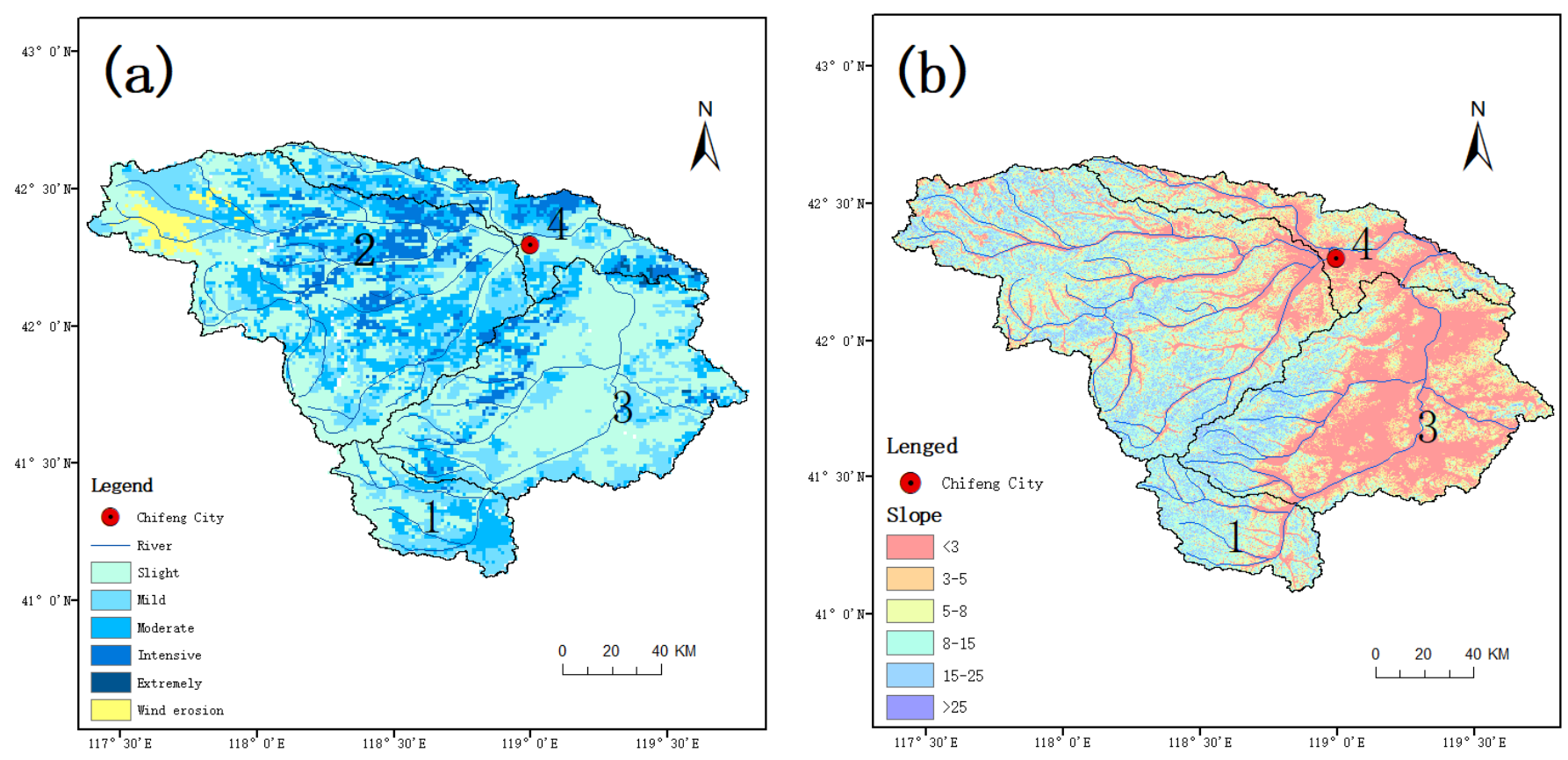

Figure 8. Distribution of soil erosion intensity and slope zone in Laohahe basin, (a) soil erosion intensity; (b) slope zone.

Table 8. Soil erosion area and rate under different slope zones in Laohahe basin.

\begin{tabular}{|c|c|c|c|c|c|c|c|c|}
\hline \multirow{2}{*}{ Slope Zone } & \multicolumn{8}{|c|}{ Area $\left(\mathrm{km}^{2}\right)$} \\
\hline & Slight & Mild & Moderate & Intensive & Extremely & Wind Erosion & Total & Rate(\%) \\
\hline$<3^{\circ}$ & 3717 & 981 & 531 & 206 & 1 & 41 & 5477 & 29.20 \\
\hline $3^{\circ}-5^{\circ}$ & 936 & 821 & 591 & 202 & 3 & $\begin{array}{l}11 \\
30\end{array}$ & 2583 & 13.77 \\
\hline $5^{\circ}-8^{\circ}$ & 807 & 918 & 896 & 394 & 5 & 52 & 3072 & 16.38 \\
\hline $8^{\circ}-15^{\circ}$ & 1737 & 1352 & 1383 & 467 & 19 & 94 & 5052 & 26.93 \\
\hline $15^{\circ}-25^{\circ}$ & 1294 & 543 & 437 & 111 & 5 & 83 & 2473 & 13.18 \\
\hline$>25^{\circ}$ & 70 & 12 & 15 & 2 & 0 & 1 & 100 & 0.53 \\
\hline Total & 8561 & 4627 & 3853 & 1382 & 33 & 301 & 18,757 & 100 \\
\hline
\end{tabular}

\subsection{Uncertainties and Limitations}

The RA-DMC method and the VIC model used in this study have some uncertainties, which may affect the results. Firstly, both methods are based on long-term measured hydrometeorological data. When calculating PET and simulating runoff, the limited number of hydrometeorological stations and their uneven distribution may affect the accuracy of the results. Secondly, the runoff change caused by climatic variability and human activity is non-linear, while the RA-DMC method used in this study assumes that these factors are linearly combined. Although there is a strong linear relationship between precipitation and runoff, the model has some uncertainties in distinguishing the effect of precipitation change and human intervention on runoff change. Thirdly, because of the lack of data, we only consider the influence of LUCC changes on runoff and do not consider the influence of other underlying surface changes (such as the change of land slopes/erosion and the geomorphology). Therefore, there are some limitations in 
discussing the impact of human intervention on runoff. Finally, uncertainties may arise from the model parameters. Although most of the model parameters have been calibrated according to the baseline runoff, the simulation results from this model can still be affected by model parameter uncertainty. Despite the uncertainties and limitations, our research is still helpful to understand the sensitivity of runoff change to runoff change to climatic variability and human intervention in the Laohahe basin. More work will be done on estimating these uncertainties in future studies.

\section{Conclusions}

Runoff in the Laohahe basin has been changing over the past 50 years. Due to the combined effects of human intervention and climatic variability, the annual runoff in most sub-basins of the Laohahe basin showed a significant decreasing trend. In the whole Laohahe basin and its three sub-basins, the change-points are in 1979, which may be associated with the basin's rapid economic and social development. So, we divided the whole time series into two periods: the baseline period from 1964 to 1979 and the change period from 1980 to 2015. This study investigated the causes of runoff changes in the Laohahe basin and quantitatively assessed climatic variability and human intervention effects on annual runoff based on RA-DMC and VIC models. The results demonstrate that about $80 \%$ of runoff reduction in the entire Laohahe basin can be attributed to human intervention during the change period of 1980-2015, while only about $20 \%$ can be attributed to climatic variability. Since the 1980s, human intervention has become the main factor causing runoff changes in the Laohahe basin. In terms of human intervention, the main reason for the severe decrease in runoff is agricultural irrigation caused by the increase of cropland; a large amount of water is drawn from rivers and reservoirs for irrigation, especially in the middle and lower reaches. At the same time, with the rapid development of the social economy, industrial water and residential water have also increased the demand for surface water.

Author Contributions: Conceptualization, L.R.; methodology, L.G., L.R., and S.J.; investigation, L.R., and L.G; writing — original draft preparation, L.G.; data curation, L.R., L.G., and S.Y.; writing-review and editing, L.R., L.G., and S.Y.; visualization, L.G.; funding acquisition, L.R., and S.J. All authors have read and agreed to the published version of the manuscript.

Funding: This study was sponsored by the National Key Research and Development Program (Grant No. 2016YFA0601500) approved by the Ministry of Science and Technology of China; supported by the Fundamental Research Funds for the Central Universities (Grant No. B200204029); the National Natural Science Foundation of China (Grant Nos. 51979069, 41807165, and 52079036); the National Natural Science Foundation of Jiangsu Province, China (Grant No. BK20180512).

Institutional Review Board Statement: Not applicable.

Informed Consent Statement: Not applicable.

Data Availability Statement: Not applicable.

Acknowledgments: Thanks to the Chinese meteorological data sharing service (http:/ / data.cma.cn/, accessed on 11 June 2020) for providing us the hydrometeorological data. We also thank the reviewers for their thoughtful comments and valuable advice.

Conflicts of Interest: The authors declare no conflict of interest.

\section{References}

1. Ren, L.L.; Wang, M.R.; Li, C.H.; Zhang, W. Impacts of human activity on river runoff in the northern area of China. J. Hydrol. 2002, 261, 204-217. [CrossRef]

2. Scanlon, B.R.; Jolly, I.; Sophocleous, M.; Zhang, L. Global impacts of conversions from natural to agricultural ecosystems on water resources: Quantity versus quality. Water Resour. Res. 2007, 43. [CrossRef]

3. Change, I.C. The Physical Science Basis; Cambridge Univ. Press: Cambridge, UK; New York, NY, USA, 2007.

4. Huntington, T.G. Evidence for intensification of the global water cycle: Review and synthesis. J. Hydrol. 2006, 319, 83-95. [CrossRef] 
5. Ye, B.S.; Yang, D.Q.; Kane, D.L. Changes in Lena River streamflow hydrology: Human impacts versus natural variations. Water Resour. Res. 2003, 39. [CrossRef]

6. Milly, P.C.D.; Dunne, K.A.; Vecchia, A.V. Global pattern of trends in streamflow and water availability in a changing climate. Nature 2005, 438, 347-350. [CrossRef] [PubMed]

7. Yong, B.; Ren, L.; Hong, Y.; Gourley, J.J.; Chen, X.; Dong, J.; Wang, W.; Shen, Y.; Hardy, J. Spatial-Temporal Changes of Water Resources in a Typical Semiarid Basin of North China over the Past 50 Years and Assessment of Possible Natural and Socioeconomic Causes. J. Hydrometeorol. 2013, 14, 1009-1034. [CrossRef]

8. Jiang, S.; Ren, L.; Yong, B.; Singh, V.P.; Yang, X.; Yuan, F. Quantifying the effects of climate variability and human intervention on runoff from the Laohahe basin in northern China using three different methods. Hydrol. Process. 2011, 25, 2492-2505. [CrossRef]

9. Brown, A.E.; Zhang, L.; McMahon, T.A.; Western, A.W.; Vertessy, R.A. A review of paired catchment studies for determining changes in water yield resulting from alterations in vegetation. J. Hydrol. 2005, 310, 28-61. [CrossRef]

10. Ma, Z.; Kang, S.; Zhang, L.; Tong, L.; Su, X. Analysis of impacts of climate variability and human activity on streamflow for a river basin in arid region of northwest China. J. Hydrol. 2008, 352, 239-249. [CrossRef]

11. Jiang, C.; Li, D.; Wang, D.; Zhang, L. Quantification and assessment of changes in ecosystem service in the Three-River Headwaters Region, China as a result of climate variability and land cover change. Ecol. Indic. 2016, 66, 199-211. [CrossRef]

12. Jiang, C.; Li, D.; Gao, Y.; Liu, W.; Zhang, L. Impact of climate variability and anthropogenic activity on streamflow in the Three Rivers Headwater Region, Tibetan Plateau, China. Theor. Appl. Climatol. 2017, 129, 667-681. [CrossRef]

13. Jiang, S.; Wang, M.; Ren, L.; Xu, C.Y.; Yuan, F.; Liu, Y.; Lu, Y.; Shen, H. A framework for quantifying the impacts of climatic variability and human intervention on hydrological drought in a semi-arid basin of Northern China. Hydrol. Process. 2019, 33, 1075-1088. [CrossRef]

14. Wang, M.; Jiang, S.; Ren, L.; Xu, C.; Yuan, F.; Liu, Y.; Yang, X. An approach for identification and quantification of hydrological drought termination characteristics of natural and human-influenced series. J. Hydrol. 2020, 590, 125384. [CrossRef]

15. $\mathrm{Xu}, \mathrm{J}$. Variation in annual runoff of the Wudinghe River as influenced by climatic variability and human activity. Quat. Int. 2011, 244, 230-237. [CrossRef]

16. Miao, C.; Ni, J.; Borthwick, A.G.L.; Yang, L. A preliminary estimate of human and natural contributions to the changes in water discharge and sediment load in the Yellow River. Glob. Planet Chang. 2011, 76, 196-205. [CrossRef]

17. Ye, X.; Zhang, Q.; Liu, J.; Li, X.; Xu, C. Distinguishing the relative impacts of climatic variability and human intervention on variation of streamflow in the Poyang Lake catchment, China. J. Hydrol. 2013, 494, 83-95. [CrossRef]

18. Chang, J.; Wang, Y.; Istanbulluoglu, E.; Bai, T.; Huang, Q.; Yang, D.; Huang, S. Impact of climatic variability and human intervention on runoff in the Weihe River Basin, China. Quat. Int. 2015, 380, 169-179. [CrossRef]

19. Zeng, S.; Zhan, C.; Sun, F.; Du, H.; Wang, F. Effects of climatic variability and human intervention on surface runoff in the Luan River Basin. Adv. Meteorol. 2015, 2015. [CrossRef]

20. Ma, H.; Yang, D.; Tan, S.K.; Gao, B.; Hu, Q. Impact of climate variability and human activity on streamflow decrease in the Miyun Reservoir catchment. J. Hydrol. 2010, 389, 317-324. [CrossRef]

21. Guoqing, W.; Jianyun, Z.; Ruimin, H.E. Impacts of environmental change on runoff in Fenhe river basin of the middle Yellow River. Adv. Water Sci. 2006, 17, 853-858. [CrossRef]

22. Kong, D.; Miao, C.; Wu, J.; Duan, Q. Impact assessment of climatic variability and human intervention on net runoff in the Yellow River Basin from 1951 to 2012. Ecol. Eng. 2016, 91, 566-573. [CrossRef]

23. Liu, C.M.; Xia, J. Water problems and hydrological research in the Yellow River and the Huai and Hai River basins of China. Hydrol. Process. 2004, 18, 2197-2210. [CrossRef]

24. Jiang, S.; Zhou, L.; Ren, L.; Wang, M.; Xu, C.; Yuan, F.; Liu, Y.; Yang, X.; Ding, Y. Development of a comprehensive framework for quantifying the impacts of climatic variability and human intervention on river hydrological health variation. J. Hydrol. 2021, 600, 126566. [CrossRef]

25. Yong, B.; Ren, L.; Hong, Y.; Wang, J.; Gourley, J.J.; Jiang, S.; Chen, X.; Wang, W. Hydrologic evaluation of Multisatellite Precipitation Analysis standard precipitation products in basins beyond its inclined latitude band: A case study in Laohahe basin, China. Water Resour. Res. 2010, 46. [CrossRef]

26. Jiang, S.; Ren, L.; Yong, B.; Fu, C.; Yang, X. Analyzing the effects of climate variability and human intervention on runoff from the Laohahe basin in northern China. Hydrol. Res. 2012, 43, 3-13. [CrossRef]

27. Liu, X.; Ren, L.; Yuan, F.; Singh, V.P.; Fang, X.; Yu, Z.; Zhang, W. Quantifying the effect of land use and land cover changes on green water and blue water in northern part of China. Hydrol. Earth Syst. Sci. 2009, 13, 735-747. [CrossRef]

28. Xinqin, W.; Li, L.I. The Drying-up of the Western Liaohe River and the Countermeasures to the Problem. J. Arid Land Resour. Environ. 2007, 21, 79-83.

29. Xiuqin, F.; Liliang, R.E.N. Detection of land use change in the Laohahe River Basin of West Liaohe River based on remote-sensing images. Geo-Inf. Sci. 2009, 11, 125-131. Available online: https://en.cnki.com.cn/Article_en/CJFDTotal-JJDL201209024.htm (accessed on 12 September 2021).

30. Mann, H.B. Nonparametric Tests Against Trend. Econometrica 1945, 13, 245-259. [CrossRef]

31. Kendall, M.G. Rank Correlation Methods. J. Inst. Actuar. 1948, 75, 140. [CrossRef]

32. Sen, P.K. Estimates of the regression coefficient based on Kendall's tau. J. Am. Stat. Assoc. 1968, 63, 1379-1389. [CrossRef] 
33. Hirsch, R.M.; Slack, J.R.; Smith, R.A. Techniques of trend analysis for monthly water quality data. Water Resour. Res. 1982, 18, 107-121. [CrossRef]

34. Pettitt, A.N. A non-parametric approach to the change-point problem. J. R. Stat. Soc. Ser. C (Appl. Stat.) 1979, $28,126-135$. [CrossRef]

35. Hurst, H.E. Long-term storage capacity of reservoirs. Trans. Am. Soc. Civ. Eng. 1951, 116, 770-799. [CrossRef] 